\title{
Primary Graft Dysfunction after Lung Transplantation
}

\author{
Gülbin Töre Altun, Mustafa Kemal Arslantaş, İsmail Cinel \\ Department of Anaesthesiology and Reanimation, Marmara University Faculty of Medicine, İstanbul, Turkey
}

Primary graft dysfunction (PGD) is a severe form of acute lung injury that is a major cause of early morbidity and mortality encountered after lung transplantation. PGD is diagnosed by pulmonary oedema with diffuse alveolar damage that manifests clinically as progressive hypoxemia with radiographic pulmonary infiltrates. Inflammatory and immunological response caused by ischaemia and reperfusion is important with regard to pathophysiology. PGD affects short- and long-term outcomes, the donor organ is the leading factor affecting these adverse ramifications. To minimize the risk of PGD, reduction of lung ischaemia time, reperfusion optimisation, prostaglandin level regulation, haemodynamic control, hormone replacement therapy, ventilator management are carried out; for research regarding donor lung preparation strategies, certain procedures are recommended. In this review, recent updates in epidemiology, pathophysiology, molecular and genetic biomarkers and technical developments affecting PGD are described.

Keywords: Primary graft dysfunction, acute lung injury, lung transplantation, early graft dysfunction, ischaemia reperfusion injury

\section{Introduction}

A lthough the most effective treatment for end-stage lung disease is lung transplantation, the success rate in lung transplantation is lower than other solid organ transplantations (1). Primary graft dysfunction (PGD), which is the major cause of early mortality and morbidity because of lung transplantation, is defined as the severe form of acute lung injury that is induced by ischaemia/reperfusion injury (2). Among $10 \%-25 \%$ of patients undergoing lung transplantation, it is the most common post-operative complication (3). Other problems caused by PGD are prolonged mechanical ventilation therapy and prolonged intensive care unit length of stay, increase in bronchiolitis obliterans syndrome risk, increase in the degradation of pulmonary function test results and increase in treatment costs (4).

\section{Standardization Studies and Incidences Associated with Primary Graft Dysfunction Diagnosis}

Until the clinical diagnosis of PGD, which is a major cause of mortality and morbidity in the post-operative period, was made, there had been a lot of confusion because of the lack of standardization in its definition. To create a framework for the forthcoming study on this important clinical situation, the International Society for Heart and Lung Transplantation (ISHLT) proposed a standardized definition for PGD (5). In this definition, after reperfusion within the first $6 \mathrm{~h}$ (T0), post 24 (T24), 48 (T48) and 72 (T72) h, the $\mathrm{PaO}_{2} / \mathrm{FiO}_{2}$ (P/F) ratio and infiltration changes in the lung should be assessed (Table 1). In the studies conducted before PGD was defined in the ISHLT guidelines, there were differences in the PGD ratios and results $(6,7)$. The incidence of stage 3 PGD was between $10 \%$ and $25 \%$ and the 30 -day mortality rate was found to be approximately $50 \%$ (3). When stage 3 PGD cases whose conditions worsened in the first $48 \mathrm{~h}$ after the organ transplant were examined, short- and long-term mortality and hospital stay were found to be associated with the P/F ratio (8). Five-year survival was alleged to be $51 \%$ and 10 -year survival was alleged to be $11 \%$ in stage 3 and over in PGD cases (9).

\section{Pathophysiology}

The events occurring during and after lung transplantation process constitutes the basic pathophysiology of PGD.

\section{Pre-transplantation factors}

Brain death leads to haemodynamic deterioration, irregularity in endocrine functions, hypothermia and release of inflammatory cytokines (10). Following the parasympathetic system activation that leads to hypothermia, hypotension and electrolyte imbalance, the sympathetic system is activated and increased arterial blood pressure and tachycardia are observed. 
Table 1. Recommended new categorization and staging system for Primary graft dysfunction

\begin{tabular}{|lcc|}
\hline Stage & P/F ratio & Chest radiography \\
\hline 0 & $>300$ & Normal \\
\hline 1 & $>300$ & Diffuse allograft infiltration \\
\hline 2 & $200-300$ & Diffuse allograft infiltration \\
\hline 3 & $<200$ & Diffuse allograft infiltration \\
\hline
\end{tabular}

The circulation chaos reduces organ perfusion but may cause severe graft ischaemia and may affect the organ quality before the organ is transplanted (11). Moreover, oxygenation of the tissues deteriorates because of warm ischaemia occurring after clamping the arteries while performing organ harvesting and after cold ischaemia that is performed to cool and protect the organs. The release of cytokines triggers organ dysfunction because of apoptosis and/or necrosis (12). In addition to oxidative stress mechanisms, during this process, there is an increase in the production of adhesion molecules in macrophages and pulmonary cells. In the early phase of reperfusion, there is an increase in IL-8, IL-12, IL-18, TNF- $\alpha$ and IFN- $\gamma$ levels, and this situation was found to be associated with an increase in tissue damage and graft function deterioration $(13,14)$.

Hypoxia occurring during ischaemia by activating endothelial cells creates an environment prone to coagulation, and this leads to irregularities after reperfusion in the microcirculatory blood flow (14). An increase is observed in smooth muscle contraction by activating the complementary system and in vascular permeability. In addition, endothelin-1, which is a potent vasoconstrictor, increases the production and release of cytokines from monocyte and macrophages and leads to the accumulation of neutrophils in the lungs (15). Furthermore, during mechanical ventilation, in brain-dead donors, lung injury may occur and deterioration of the damage is possible (10). This damage contributes to PGD development after transplantation.

\section{Post-transplantation factors}

PGD is clinically and histologically similar to Acute Respiratory Distress Syndrome (ARDS). Mechanical ventilation application, just as in ARDS, can also be an iatrogenic factor in PGD $(16,17)$. Therefore, in many transplant centres, lung protective ventilation strategies are implemented for the recipients. Apart from mechanical ventilation, some factors, such as fluid overload, haemodynamic deterioration and infection, may also cause PGD development and lung function deterioration in the recipients.

Innate immune responses are associated with PGD development after lung transplantation. The importance of the innate immune system activation has been recently demonstrated during the onset and spread of ischaemia reperfusion injury. Studies in which biomarkers in plasma and genetic methods were used have demonstrated that PGD is associated with the innate immunity pathways of a Toll-like receptor-mediated injury $(18,19)$.

\section{Clinical Risk Factors}

\section{i. Donor-related risk factors}

Donor-related risk factors can be categorized as hereditary and acquired. An advanced donor age is a hereditary risk factor as in other solid organ transplants. PGD risk increases in donors older than $32-45$ years (6). However, if there are no other risk factors, advanced age does not constitute an impediment to use of the donor lungs (10). A study that examined 255 lung transplant patients indicated that in addition to the age factor, the female gender and African-American race were also associated with an increased risk for PGD (6).

Among the lung donor-acquired risk factors for PGD are haemodynamic instability because of brain death, prolonged mechanical ventilation, bronchoaspiration, pneumonia, underlying trauma and excessive blood transfusion (10). In addition, the presence of a fat embolism from the donor increases the risk of PGD development by 25 fold, and presence of a thromboembolism increases the risk by 5 fold (20). In a large-scale multicentre study, stage 3 PGD patients were evaluated and some new risk factors were identified, including transplanting an organ from a donor with a smoking history, high $\mathrm{FiO}_{2}$ in an allograft re-perfusion, pre-operative sarcoidosis or hypertension in pulmonary arteries, cardiopulmonary bypass ( $\mathrm{CPB}$ ), single lung transplantation, excessive blood component transfusion and obese recipients (4).

\section{ii. Recipient-related risk factors}

Because of variabilities in the definition of PGD and the studies being conducted on only a small number of patients, there is no conclusive evidence yet. However, the recipient's age, gender, race, body weight, presence of underlying liver and kidney dysfunction, presence of left heart disease and some drugs used before surgery (inotropic agents, steroids) are all factors directly associated with PGD development (21). Furthermore, the recipient's having pulmonary arterial hypertension increases PGD risk $(6,21)$. In contrast, in pulmonary fibrosis patients who had an increase in pre-transplant pulmonary artery pressure, PGD risk increased (22). Although there is no strong evidence regarding PGD's relationship with other diseases, COPD patients have the lowest risk for PGD.

\section{iii. Surgery-related risk factors}

Performing single or double lung transplantation has not been demonstrated as an independent risk factor for PGD development. Because patients undergoing double lung transplant are usually patients with $\mathrm{PAH}$ and this condition often requires the use of $\mathrm{CPB}$ during transplant. The notion of a relationship between PGD and CPB that is independent from the utilization indication is controversial. Because pre-operatively diagnosed $\mathrm{PAH}$ patients often require the use of intraoperative cardiopulmonary bypass and as these patients often develop PGD, the application of CPB to these 
patients affects the connection between PAH and PGD (4, 23). Conversely, when $\mathrm{CPB}$ is used in patients without the pre-operative diagnosis of $\mathrm{PAH}$, early stage results worsen and the risk of death increases $(4,24)$.

Another risk factor associated with surgery is the transfusion of blood components. It is known that intraoperative transfusions cause transfusion-related lung injury (TRALI), which is similar to ARDS and PGD in the post-operative stage and should be considered in the differential diagnosis (25).

It has been indicated that mortality increases in patients who received more than four units of intraoperative blood transfusion (26). Moreover, it was indicated in the same study that in patients who received numerous transfusions, an increase in renal replacement therapy, PGD, a requirement to use post-operative extracorporeal membrane oxygenation (ECMO), sepsis, infections, re-transplantation and repeated intensive care was observed. Thus, it has been demonstrated that there is a strong negative impact of an intraoperatively performed transfusion on lung transplantation results (26).

\section{Clinical findings}

The most important clinical finding for PGD is deterioration in oxygenation and with respect to radiology, the presence of diffuse pulmonary opacities in the transplanted lung in the first $72 \mathrm{~h}$ after transplantation (13). Other clinical findings are a decrease in pulmonary compliance, increase in pulmonary vessel resistance and formation of intrapulmonary shunts (5).

According to staging performed by ISHLT for determining the severity of PGD, being stage 3 PGD within the 72nd hour is a powerful indicator that these patients' short- and long-term results would be unfavourable (27).

\section{Molecular markers}

Sensitivity and specificity are revealed as the survival and individual biomarker profiles of the ISHLT rating system (27). However, because PGD's clinical identification is categorical and may not completely reflect the PGD spectrum, it has a limited potential in inter-research use (28).

The most preferred molecular markers concerning mechanisms involved in the pathophysiology for acute respiratory distress syndrome and PGD are biomarkers related to endothelial damage, epithelial damage and coagulation cascade. The markers that are mentioned are intracellular adhesion molecule-1, surfactant protein-1, plasminogen activator inhibitor, soluble receptor for advance glycation end products and protein C.

\section{Prevention of PGD development and treatment}

Currently, there are few controlled studies that are performed on people for the prevention and treatment of PGD development. To reduce the ischaemia reperfusion injury, lung preventive methods in particular are focused on. Therefore, time, reperfusion optimization, regulation of prostaglandin levels, haemodynamic control, hormone replacement, ventilator management and donor lung preparation strategies. To decrease PGD incidence, strategies, such as using endogenous cytoprotective substances (prostaglandins), nitric oxide, surfactant, adenosine or inhibition of pro-inflammatory mediators and/or elimination of free oxygen radicals, have been used (29). Furthermore, for the inhibition of neutrophils and neutrophil-borne mediators, free oxygen radicals, cytokines, proteases, lipid mediators, adhesion molecules and complement cascade inhibitors have been studied (29). However, to date, most of these studies are experimental studies conducted on animals.

During lung transplantation, several procedures are also followed to prevent PGD development. These include methods to limit the length of cold ischaemia and extending reperfusion time. The most appropriate and acceptable temperature and duration of cold ischaemia is not completely known. Generally, many centres store the organs at a temperature between $4^{\circ} \mathrm{C}$ and $8^{\circ} \mathrm{C}$ and consider an ischaemia duration of up to $8 \mathrm{~h}$ acceptable (10). An ischaemia time that exceeds $8 \mathrm{~h}$ increases the risk of ischaemia reperfusion injury and PGD. In general, it is recommended to evaluate the ischaemia duration along with other risk factors and then make a transplant decision (13).

The reperfusion technique may also pose a risk of PGD. Experimental studies have demonstrated that pulmonary artery pressures are important in the first 10 min of reperfusion (3032). For this purpose, during transplantation, after the vascular anastomosis, the reperfusion clamp is gradually opened for a duration longer than 10 minutes. If CPB has been used during transplantation, the reperfusion rate can be controlled by the pump flow.

Mechanical ventilation is also very important in patients undergoing lung transplantation. Many experimental and clinical studies have revealed that mechanical ventilation may aggravate a pre-existing lung injury and may lead to ventilator-associated lung injury (33). In experimental studies, it has been indicated that compared with those that were provided lung protective ventilation, administering a high tidal volume and low positive end-expiratory pressure (PEEP) worsens lung function after $3 \mathrm{~h}$ of reperfusion (34). During lung transplantation, most centres implement their own strategy of lung protective mechanical ventilation from the beginning of the reperfusion period. In some centres, prior to reperfusion, the lung allograft is continuously and gradually inflated to $20 \mathrm{~cm} \mathrm{H}_{2} \mathrm{O}$ and then pressure-controlled mechanical ventilation is performed, provided that $\mathrm{FiO}_{2}$ is $50 \%$, PEEP is 5 $\mathrm{cm} \mathrm{H}_{2} \mathrm{O}$ and airway peak pressure is $20-25 \mathrm{~cm} \mathrm{H}_{2} \mathrm{O}$ (35).

\section{Treatment}

The basic treatment strategy for PGD is buying time to heal the PGD-associated lung injury and implementing supportive treatments to reduce the secondary organ damage. The 
principles of treatment are similar to those in ARDS, which include lung protective mechanical ventilation, avoiding excessive fluid application, haematocrit (25\%-30\% range) and the optimization of coagulation parameters (36).

Inhaled nitric oxide (iNO) can theoretically correct a ventilation-perfusion mismatch and, without affecting the systemic blood pressure, lowers the pulmonary artery pressure. In some case series, it has been shown that iNO therapy corrects oxygenation, reduces average pulmonary artery pressure and reduces the duration of mechanical ventilation $(37,38)$. 10-20 ppm iNO use is recommended in patients with persistent hypoxemia and increased pulmonary artery pressure for the treatment of stage 3 PGD patients (37). As a side effect methaemoglobinemia can be observed in $6 \%$ of the patients.(39).

In severe PGD patients who failed to respond to all conventional treatments and iNO use, as a last life-saving resort option, ECMO treatment is used by many transplant centres (37). ECMO corrects PGD-induced hypoxemia and by providing necessary gas exchange it helps protection of the lungs from the potential harmful effects of aggressive mechanical ventilation and from hypoxia in the healing process $(40,41)$. Since it provides a cardiac support opportunity in PGD treatment, venoarterial (VA) ECMO is the most frequently used. Apart from that, veno-venous (VV) ECMO that can provide adequate gas exchange and oxygenation and has positive impact on survival may also be used for this purpose. Existing data indicates that ECMO should be used within the first 24 $h$ in which severe PGD starts (37). In particular, VV ECMO, in which fewer complications are observed, may be preferred in order to ensure adequate oxygenation and gas exchange for patients who do not need haemodynamic support (42).

Experimental Approaches in the Prevention and Treatment of Primary Graft Dysfunction Development

In order for the treatment and prevention of PGD development, some studies are being carried out on a number of agents, such as prostaglandins, surfactant therapy, complement inhibition, platelet-activating factor antagonists (PAF), although they cannot yet be applied in routine clinical practice.

Preconditioning: When the tissue is exposed to an insult it can develop tolerance for future similar ones or more severe insults. This biological adaptation form establishes the basis of preconditioning (43). For example; it has been shown that methods such as brief recurrent ischaemia applications, involving increasing the heat and triggering preconditioning via pharmacological agents reduce damage in the lungs of most patients (13).

Gene therapy: Gene-based therapies offer the potential to resist the stress that is encountered during transplantation process in genetically modified organs. For example, it has been shown that in single lung transplant model in rats, implementing the gene coding of human IL-10 anti-inflam- matory cytokines transtracheally to the donors reduces ischaemia-reperfusion injury and improves lung functions 12-24 $\mathrm{h}$ before the removal of the organ (44). If gene transfer can be achieved, it may be possible to protect human lungs from ischaemia-reperfusion injury and immunological damage with gene therapy (13).

Ventilation: Lung protective ventilation strategies cover a small tidal volume $\left(6-8 \mathrm{~mL} \mathrm{~kg}^{-1}\right)$, high PEEP $(8 / 10 \mathrm{~cm}$

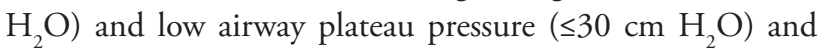
the avoidance of over-distension of the alveoli. Optimal pulmonary care of potential donors improves the success of lung transplants. Recruitment manoeuvres with related protective ventilation strategies double the number of suitable lungs for transplantation (45). For the diagnosis of brain death, applying an apnoea test via "continuous positive airway pressure (CPAP)", using a closed circuit tracheal aspiration system and, after the conditions that require separation from the ventilator, using recruitment manoeuvres are recommended (45). Since the most common complication after transplantation is respiratory failure, it is important to develop a treatment approach with protective ventilation strategies (46). The best strategy to prefer is one with ventilation that provides a low tidal volume, moderate PEEP levels, inspiratory pressure lower than $20 \mathrm{~cm} \mathrm{H}_{2} \mathrm{O}$ and permissive hypercapnia. It is not routinely necessary to use neuromuscular blocking agents and extubation should be tried via a rapid reduction of $\mathrm{FiO}_{2}$ to the extent of the tolerance point and with PEEP support (45). In many cases, successful extubation is performed within $24 \mathrm{~h}$. It should be noted that early implementation of ECMO with the right indication improves the survival rate by $50 \%-80 \%$. Early separation from mechanical ventilation is important. While the benefits of non-invasive ventilation are controversial, early tracheostomy (percutaneous technique) is a preferred method. Although there is not much data related to the use of a protective ventilatory approach on patients after transplantation, it is thought to be useful in accordance with the recommendations of the evidence of other acute lung injury causes.

\section{Conclusion}

Apart from PGD's being an important cause of mortality and morbidity that develop after lung transplantation, its pathophysiology has been more clearly presented in recent years, and the studies performed in order to increase awareness related to its definition are promising. Besides, experimental studies that involve planned and randomized clinical studies will lead to the recognition of this syndrome and provide better results for its treatment. It is important to increase the awareness on PGD and the conscious use of advanced technologies in perioperative period with intensive care process.

Peer-review: Externally peer-reviewed. 
Author Contributions: Concept - İ.C.; Design - İ.C.; Supervision İ.C.; Literature Review - G.T.A., M.K.A.; Writer - G.T.A., M.K.A.; Critical Review - İ.C.

Conflict of Interest: No conflict of interest was declared by the authors.

Financial Disclosure: The authors declared that this study has received no financial support.

\section{References}

1. Meyer KC. Lung transplantation. F1000Prime Rep 2013; 5: 16. [CrossRef]

2. Lee JC, Christie JD. Primary graft dysfunction. Clin Chest Med 2011; 32: 279-93. [CrossRef]

3. Christie JD, Kotloff RM, Ahya VN, Tino G, Pochettino A, Gaughan C, et al. The effect of primary graft dysfunction on survival after lung transplantation. Am J Respir Crit Care Med 2005; 171: 1312-6. [CrossRef]

4. Diamond JM, Lee JC, Kawut SM, Shah RJ, Localio AR, Bellamy SL, et al. Clinical risk factors for primary graft dysfunction after lung transplantation. Am J Respir Crit Care Med 2013; 187: 527-34. [CrossRef]

5. Christie JD, Carby M, Bag R, Corris P, Hertz M, Weill D, et al. Report of the ISHLT Working Group on Primary Lung Graft Dysfunction part II: definition. A consensus statement of the International Society for Heart and Lung Transplantation. J Heart Lung Transplant 2005; 24: 1454-9. [CrossRef]

6. Christie JD, Kotloff RM, Pochettino A, Arcasoy SM, Rosengard BR, Landis JR, et al. Clinical risk factors for primary graft failure following lung transplantation. Chest 2003; 124: $1232-$ 41. [CrossRef]

7. Thabut G, Vinatier I, Stern JB, Leseche G, Loirat P, Fournier M, et al. Primary graft failure following lung transplantation: predictive factors of mortality. Chest 2002; 121: 1876-82. [CrossRef]

8. Prekker ME, Nath DS, Walker AR, Johnson AC, Hertz MI, Herrington CS, et al. Validation of the proposed International Society for Heart and Lung Transplantation grading system for primary graft dysfunction after lung transplantation. J Heart Lung Transplant 2006; 25: 371-8. [CrossRef]

9. Whitson BA, Prekker ME, Herrington CS, Whelan TP, Radosevich DM, Hertz MI, et al. Primary graft dysfunction and long-term pulmonary function after lung transplantation. J Heart Lung Transplant 2007; 26: 1004-11. [CrossRef]

10. De Perrot M, Bonser RS, Dark J, Kelly RF, McGiffin D, Menza $\mathrm{R}$, et al. Report of the ISHLT Working Group on Primary Lung Graft Dysfunction part III: donor-related risk factors and markers. J Heart Lung Transplant 2005; 24: 1460-7. [CrossRef]

11. Zhai Y, Busuttil RW, Kupiec-Weglinski JW. Liver ischemia and reperfusion injury: new insights into mechanisms of innate-adaptive immune-mediated tissue inflammation. Am J Transplant 2011; 11: 1563-9. [CrossRef]

12. Cinel I, Opal SM. Molecular biology of inflammation and sepsis: a primer. Crit Care Med 2009; 37: 291-304. [CrossRef]

13. De Perrot M, Liu M, Waddell TK, Keshavjee S. Ischemia-reperfusion-induced lung injury. Am J Respir Crit Care Med 2003; 167: 490-511. [CrossRef]

14. De Perrot M, Sekine Y, Fischer S, Waddell TK, McRae K, Liu $\mathrm{M}$, et al. Interleukin-8 release during early reperfusion predicts graft function in human lung transplantation. Am J Respir Crit Care Med 2002; 165: 211-5. [CrossRef]

15. Sato Y, Hogg JC, English D, van Eeden SF. Endothelin-1 changes polymorphonuclear leukocytes' deformability and CD11b expression and promotes their retention in the lung. Am J Respir Cell Mol Biol 2000; 23: 404-10. [CrossRef]

16. Beer A, Reed RM, Bolukbas S, Budev M, Chaux G, Zamora $\mathrm{MR}$, et al. Mechanical ventilation after lung transplantation. An international survey of practices and preferences. Ann Am Thorac Soc 2014; 11: 546-53. [CrossRef]

17. Verbeek GL, Myles PS. Intraoperative protective ventilation strategies in lung transplantation. Transplant Rev 2013; 27: 30-5. [CrossRef]

18. Cantu E, Lederer DJ, Meyer K, Milewski K, Suzuki Y, Shah RJ, et al. Gene set enrichment analysis identifies key innate immune pathways in primary graft dysfunction after lung transplantation. Am J Transplant 2013; 13: 1898-904. [CrossRef]

19. Diamond JM, Wigfield CH. Role of innate immunity in primary graft dysfunction after lung transplantation. Curr Opin Organ Transplant 2013; 18: 518-23. [CrossRef]

20. Oto T, Excell L, Griffiths AP, Levvey BJ, Snell GI. The implications of pulmonary embolism in a multiorgan donor for subsequent pulmonary, renal, and cardiac transplantation. J Heart Lung Transplant 2008; 27: 78-85. [CrossRef]

21. Barr ML, Kawut SM, Whelan TP, Girgis R, Bottcher H, Sonett J, et al. Report of the ISHLT Working Group on Primary Lung Graft Dysfunction part IV: recipient-related risk factors and markers. J Heart Lung Transplant 2005; 24: 1468-82. [CrossRef]

22. Fang A, Studer S, Kawut SM, Ahya VN, Lee J, Wille K, et al. Elevated pulmonary artery pressure is a risk factor for primary graft dysfunction following lung transplantation for idiopathic pulmonary fibrosis. Chest 2011; 139: 782-7. [CrossRef]

23. Shigemura N, Horai T, Bhama JK, D'Cunha J, Zaldonis D, Toyoda Y, et al. Lung transplantation with lungs from older donors: recipient and surgical factors affect outcomes. Transplantation 2014; 98: 903-8. [CrossRef]

24. Cassivi SD, Meyers BF, Battafarano RJ, Guthrie TJ, Trulock EP, Lynch JP, et al. Thirteen-year experience in lung transplantation for emphysema. Ann Thorac Surg 2002; 74: 1663-9. [CrossRef]

25. Goodwin J, Tinckam K, denHollander N, Haroon A, Keshavjee S, Cserti-Gazdewich CM. Transfusion-related acute lung injury (TRALI) in graft by blood donor antibodies against host leukocytes. J Heart Lung Transplant 2010; 29: 1067-70. [CrossRef]

26. Weber D, Cottini SR, Locher P, Wenger U, Stehberger PA, Fasshauer M, et al. Association of intraoperative transfusion of blood products with mortality in lung transplant recipients. Perioper Med 2013; 2: 20. [CrossRef]

27. Christie JD, Bellamy S, Ware LB, Lederer D, Hadjiliadis D, Lee J, et al. Construct validity of the definition of primary graft dysfunction after lung transplantation. J Heart Lung Transplant 2010; 29: 1231-9. [CrossRef]

28. Oto T, Griffiths AP, Levvey BJ, Pilcher DV, Williams TJ, Snell GI. Definitions of primary graft dysfunction after lung transplantation: differences between bilateral and single lung transplantation. J Thorac Cardiovasc Surg 2006; 132: 140-7. [CrossRef]

29. Suzuki Y, Cantu E, Christie JD. Primary graft dysfunction. Semin Respir Crit Care Med 2013; 34: 305-19. [CrossRef] 
30. Pierre AF, DeCampos KN, Liu M, Edwards V, Cutz E, Slutsky AS, et al. Rapid reperfusion causes stress failure in ischemic rat lungs. J Thorac Cardiovasc Surg 1998; 116: 932-42. [CrossRef]

31. Bhabra MS, Hopkinson DN, Shaw TE, Onwu N, Hooper TL. Controlled reperfusion protects lung grafts during a transient early increase in permeability. Ann Thorac Surg 1998; 65: 187-92. [CrossRef]

32. Halldorsson A, Kronon M, Allen BS, Bolling KS, Wang T, Rahman $S$, et al. Controlled reperfusion after lung ischemia: implications for improved function after lung transplantation. J Thorac Cardiovasc Surg 1998; 115: 415-24. [CrossRef]

33. Dos Santos CC, Slutsky AS. Invited review: mechanisms of ventilator-induced lung injury: a perspective. J Appl Physiol 2000; 89: 1645-55.

34. De Perrot M, Imai Y, Volgyesi GA, Waddell TK, Liu M, Mullen JB, et al. Effect of ventilator-induced lung injury on the development of reperfusion injury in a rat lung transplant model. J Thorac Cardiovasc Surg 2002; 124: 1137-44. [CrossRef]

35. McRae KM. Pulmonary transplantation. Curr Opin Anaesthesiol 2000; 13: 53-9. [CrossRef]

36. Hoffman SA, Robinson N, Christie JD. Primary graft dysfunction. Curr Opin Organ Transplant 2007; 12: 473-8. [CrossRef]

37. Shargall Y, Guenther G, Ahya VN, Ardehali A, Singhal A, Keshavjee S, et al. Report of the ISHLT Working Group on Primary Lung Graft Dysfunction part VI: treatment. J Heart Lung Transplant 2005; 24: 1489-500. [CrossRef]

38. Kemming GI, Merkel MJ, Schallerer A, Habler OP, Kleen MS, Haller M, et al. Inhaled nitric oxide (NO) for the treatment of early allograft failure after lung transplantation. Munich Lung Transplant Group. Intensive Care Med 1998; 24: 1173-80. [CrossRef]
39. Adatia I, Lillehei C, Arnold JH, Thompson JE, Palazzo R, Fackler JC, et al. Inhaled nitric oxide in the treatment of postoperative graft dysfunction after lung transplantation. Ann Thorac Surg 1994; 57: 1311-8. [CrossRef]

40. Meyers BF, Sundt TM 3rd, Henry S, Trulock EP, Guthrie T, Cooper JD, et al. Selective use of extracorporeal membrane oxygenation is warranted after lung transplantation. J Thorac Cardiovasc Surg 2000; 120: 20-6. [CrossRef]

41. Hartwig MG, Walczak R, Lin SS, Davis RD. Improved survival but marginal allograft function in patients treated with extracorporeal membrane oxygenation after lung transplantation. Ann Thorac Surg 2012; 93: 366-71. [CrossRef]

42. Arslantaş MK, Cinel İ, Günerli A. Sepsis ve ekstrakorporeal membran oksijenizasyonu. Türk Yoğun Bakım Derneği Dergisi 2013; 11: 86-92. [CrossRef]

43. Umuroğlu Öncel T, Çorman Dinçer P, Cinel İ. İskemik önkoşullamanın klinik önemi. Göğüs-Kalp-Damar Anestezi ve Yoğun Bakım Derneği Dergisi 2012; 18: 1-10.

44. Fischer S, Liu M, Maclean AA, De Perrot M, Bai X, Cardella J, et al. In vivo donor adenoviral-mediated transtracheal transfection of human IL-10 (HIL-10) gene ameliorates ischemia-reperfusion (IR) injury and enhances transplanted lung function. J Heart Lung Transplant 2001; 20: 152-3. [CrossRef]

45. Lucangelo U, Del Sorbo L, Boffini M, Ranieri VM. Protective ventilation for lung transplantation. Curr Opin Anaesthesiol 2012; 25: 170-4. [CrossRef]

46. Rose L. Clinical application of ventilator modes: Ventilatory strategies for lung protection. Aust Crit Care 2010; 23: 71-80. [CrossRef] 